\title{
SQUIB
}

\section{Gapping is not only low coordination}

\author{
Aleksandr Kalinin \\ Queen Mary University of London, GB \\ a.kalinin@qmul.ac.uk
}

This squib is concerned with the validity of an approach to Gapping that exploits low coordination and ATB-movement (Johnson 2009). In this squib, I show that low coordination combined with ATB-movement has the following problems: (1) ATB-movement is not compatible with the Copy theory of Movement; (2) there is no universal correlation between partial VP/VP-topicalization and Gapping; (3) Gapping is possible in CP coordination, violating the low coordination requirement.

Keywords: Gapping; low coordination; ATB movement; ellipsis; Copy Theory; identity requirement

\section{Introduction}

This squib is concerned with the validity of an approach to Gapping that exploits low coordination and ATB movement (Johnson 2009). ${ }^{1}$ Gapping is a subtype of verbal ellipsis, which is exemplified by the following sentences:

a. Some will eat poi for breakfast and others for lunch.

(Johnson 2009: 305)

b. Russian

Odni budut est' poi na zavtrak, a drugie some.NOM will eat poi.ACC for breakfast.ACC and others.NOM budut est' poi na obed.

will eat poi.ACC for lunch.ACC

'Some will eat poi for breakfast and others will eat poi for lunch.'

In (1), Gapping elides the second occurrence of the finite verb and the direct object, which are contrasted with the counterparts in the first conjunct. Generally speaking, Gapping deletes finite verbs and other repeated elements that can be restored from the preceding conjunct.

Johnson (2009) analyses Gapping as ATB movement. He represents the rule of Gapping as a set of movement operations, which can only take place in coordination constructions when two $v$ Ps are coordinated (Johnson refers to such constructions as 'low coordination'):

(2) a. Some will eat poi for breakfast and others for lunch.

(Johnson 2009: 305)

\footnotetext{
${ }^{1}$ There are approaches to Gapping that use low coordination and ellipsis (Toosarvandani 2013).
} 
b. (Johnson 2009: 308)

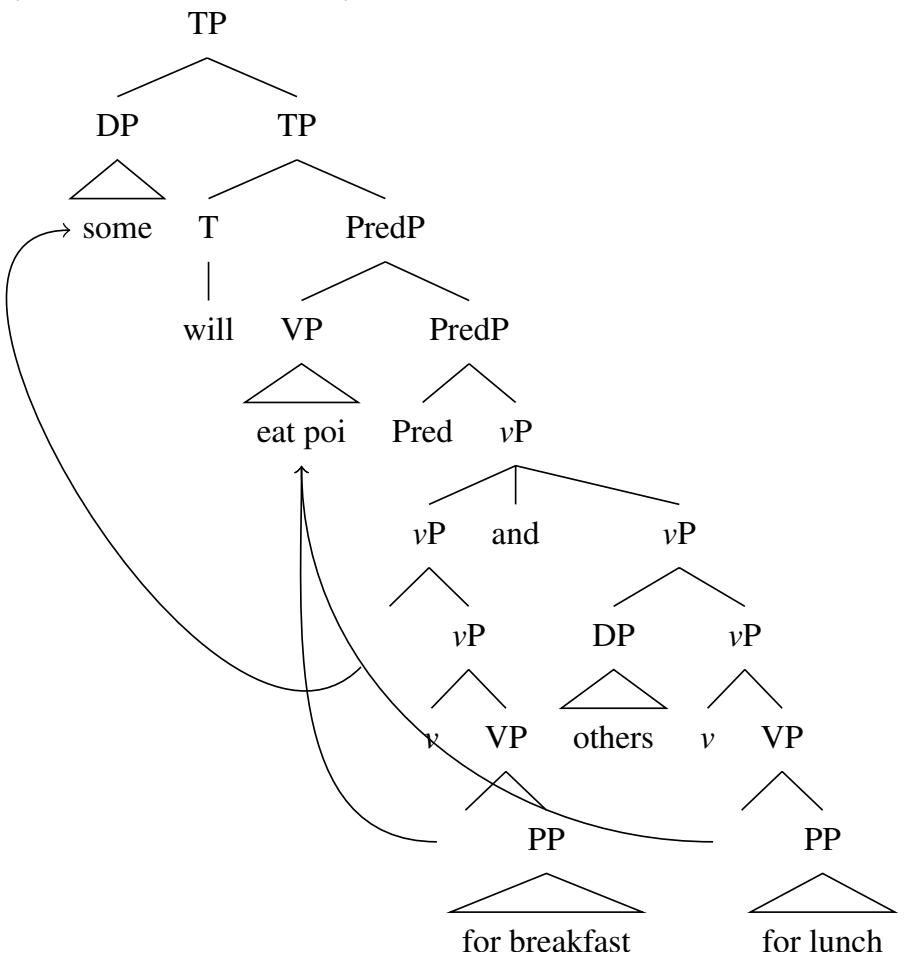

Example (2b) represents the key traits of Johnson's analysis of Gapping. The derivational step that generates Gapping involves ATB movement: the VPs eat poi are moved into [Spec, PredP], a position which is specifically reserved for VP movement. Under this analysis, Gapping does not involve ellipsis and it is completely derived by ATB movement.

The approach to Gapping outlined in Johnson (2009) has a number of benefits. Firstly, it successfully captures the fact that Gapping does not take place within an embedded clause if the antecedent clause is not embedded. Thus, Gapping and its antecedent must be at the same structural level:

a. *Some had eaten mussels and she claims that others hateaten shrimp. (Johnson 2009: 293)

b. $\quad\left[_{T P}\right.$ Some had eaten mussels $]$ and $\left[_{T P}\right.$ she claims $\left[_{C P}\right.$ that others had eaten shrimp.]]

In (2), the Gapping clause is a CP and the antecedent clause is a TP. Consequently, each clause contains a separate T-head. This is not compatible with the idea that Gapping involves low coordination of VPs.

Johnson (2009) also provides a straightforward explanation of the requirement that Gapping is restricted to coordination, as only coordinating conjunctions can coordinate $\nu \mathrm{P}$, thus generating low coordination:

(4) a. *Some had eaten mussels because others had eaten shrimp.

(Johnson 2009: 293)

b. Some had eaten mussels and others had eaten shrimp.

The other important virtue of Johnson's analysis is wide scope of the modals that is available under Gapping (see Agafonova 2014 for Russian and Lin 2002 for English). In the case of English, (5a) can only have the wide scope reading paraphrased in (5b): 
(5) a. Ward can't eat caviar and Mary eat beans.

(Lin 2002: 13)

b. It can't be the case that Ward eats caviar while Mary eats beans.

(Lin 2002: 13)

Potentially (5a) can also have the narrow scope reading:

(6) Ward and Mary have different food allergies. Ward can't eat caviar and Mary can't eat beans.

Low coordination can successfully derive wide modal scope:

(7)

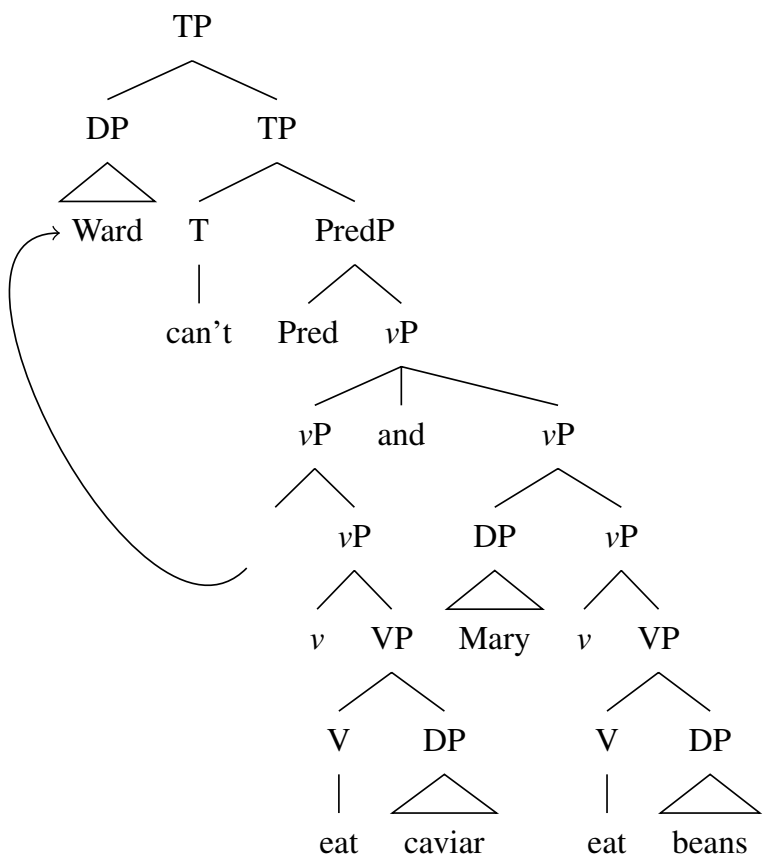

In (6), the modal verb can't is the only T-head, which is located above the coordinated $v \mathrm{Ps}$ ( $\left[_{v P}\left[_{v P}\right.\right.$ Ward eat caviar] [and] $\left[_{v P}\right.$ Mary eat beans $\left.]\right]$ ) and c-commands low coordination. Thus, can't has scope over both conjuncts, giving rise to the wide scope reading. Furthermore, the effect of modal wide scope seems to hold across languages, including Russian. According to Agafonova (2014), Russian Gapping derives the wide scope of modals as one of the possible readings. Hence, low coordination should be preferred for the analysis of such cases.
a. Petja možet est' ikru, a Vanja est' boby.
Peter can eat caviar and Vanja eat beans
'Peter can eat caviar and Vanja eat beans.'
b. It is possible that Petja eats caviar and Vanja eats beans.
(Agafonova 2014: 8)

Despite these advantages, I argue that low coordination cannot be the only source of Gapping. In this squib, I show that Gapping is possible in CP coordination, violating the low coordination requirement. I also argue that this problem can be solved if one assumes that Gapping can be derived either from low coordination of $\nu$ Ps and high coordination of TPs/CPs. Instead of using ATB movement, I exploit Parallel Merge to derive 
Gapping. Although a more traditional deletion-based analysis is also compatible with the two source hypothesis of Gapping, Parallel Merge appears to be a more appealing option. The corroborating evidence comes from prohibition of voice mismatches (see Merchant 2013 for detailed discussion). Under Gapping, all conjuncts must match in voice:
a. English
*Roses were bought by Peter, and Sam bought violets.
b. English
Peter bought roses, and Sam bought violets.
c. Russian
*Rozy byli kupleny Petej, a Vasja kupil fialki. roses.NOM were bought Peter.INS and Vasja.NOM bought violets.ACC 'Roses were bought by Peter, and Sam bought violets.'

d. Russian

Petja kupil rozy, a Vasja kupil fialki.

Peter.NOM bought roses.ACC and Vasja.NOM bought violets.ACC

'Peter bought roses, and Jan bought violets.'

In (9), the ungrammatical sentences have active antecedent verbs and passive gapped verbs, while the acceptable ones have verbs matching in voice features. With Gapping being incompatible with voice mismatches, Barbara Citko proposes Parallel Merge as a straightforward solution to this issue (see Citko 2011). In Citko (2011), V and $v$ are shared between conjuncts. Since Citko assumes that $v$ is the host of voice, $v$-sharing prevents the voice feature from having mismatching values. In this squib, I follow Citko (2011) in using Parallel Merge to derive Gapping. I expand on this idea in section 3 .

\section{Gapping in CP coordination}

The focus of the present section is the high coordination itself. Johnson's analysis of Gapping requires $v \mathrm{P}$ coordination, which is defined as low coordination. Contrary to the prediction of Johnson (2009), I will demonstrate that Gapping is grammatical in CP-coordination and cannot be completely reduced to low coordination. This section discusses the Russian conjunction li...li 'whether...or', which is argued to be an example of CP coordination compatible with Gapping:
Ja ne znaju, myši
li zašuršat
na čerdake, krysy li
1SG not know mice.NOM whether rustle.PRS.3PL on attic.LOC rats.NOM or zašuršat $\quad \mathrm{v}$ podvale.
rustle.PRS.3PL in basement.LOC
'I do not know whether mice rustle in the attic or rats rustle in the basement.'

The backbone of my argument is syntactic behaviour of the Russian conjunction li 'whether'. $\mathrm{Li}$ 'whether' is an interrogative complementizer which possesses a Q-feature (see Bailyn 2012). The Q-feature indicates that $l i$ has interrogative force. There are two ways to value the Q-feature of $l i$. Firstly, a main verb of a TP headed by li can be merged with li to value the Q-feature. Secondly, an arbitrary phrase from a TP headed by li can move to $[\mathrm{Spec}, \mathrm{CP}]$ and value the Q-feature of li. Consider, for instance, the following sentences: 
a. Petja ne znaet, $\left[{ }_{C P}\left[{ }_{C}\right.\right.$ umeet $\left._{V} \mathrm{li}_{C}\right]$ Saša umeet igrat' na Peter.NOM not knows can whether Alex.NOM can play on skripke]. violin.LOC

'Peter does not know whether Alex can play the violin.'

b. Petja ne znaet, $\left[_{C P}\left[_{S p e c, C P}\right.\right.$ na skripke $] \quad\left[_{C}\right.$ li $]$ Saša Peter.NOM not knows on violin.LOC whether Alex.NOM umeet igrat' skripke]. can play on violin.LOC

'Peter does not know whether it is the violin that Alex can play.'

In (11a), the main verb of the embedded clause, which is umeet 'can', is merged with li 'whether' to value the Q-feature of $l i$. In $((11 b))$, the PP "na skripke" 'on violin' moves to [Spec,CP] and values the Q-feature of li. Note that the Q-feature of li cannot be valued without movement to the C-head or [Spec, CP]:

$$
\begin{aligned}
& \text { *Petja ne znaet, }\left[\begin{array}{ll}
{ }_{C P} & {\left[l_{C} i_{C}\right.}
\end{array}\right. \text { Saša umeet igrat' na skripke]. } \\
& \text { Peter.NOM not knows } \\
& \text { whether Alex.NOM can play on violin.LOC } \\
& \text { 'Peter does not know whether Alex can play the violin.' }
\end{aligned}
$$

The claim that $l i$ 'whether' is a complementizer can also be corroborated by interaction with sluicing. Like its English counterpart, Russian sluicing, which is TP deletion, can be licensed by a null interrogative complementizer. This licensing condition on sluicing was originally formulated in Merchant (2001). In ((13)), the Wh-phrase kogda 'when' moves to [Spec, CP] to value a Q-feature and a Wh-feature of a null C. The Wh-feature ensures that only Wh-phrases can move to [Spec, CP]. After the features of the null $\mathrm{C}$ have been valued, the remaining TP is deleted:

$$
\begin{aligned}
& \text { Petja prišel domoj, no ja ne znaju }\left[_ { C P } \operatorname { k o g d a } _ { i } C _ { + Q _ { i } + W h } \left[_{T P}\right.\right. \text { Petja } \\
& \text { Peter.NOM came home but 1SG not know when } \\
& \text { prišet domoj } \left.\left.t_{i}\right]\right] \\
& \text { 'Peter came home but I do not know when.' }
\end{aligned}
$$

Although Merchant assumed that only Wh-phrases can move to [Spec, CP] and trigger sluicing (see Merchant 2001: 60), this hypothesis does not hold for Russian sluicing. As is demonstrated in (14), li 'whether' is a overt complementizer which does not have the Wh-feature. Nevertheless, the Q-feature of $l i$ can be valued by a DP with no Wh-elements. Valuation of the Q-feature of li licenses sluicing:

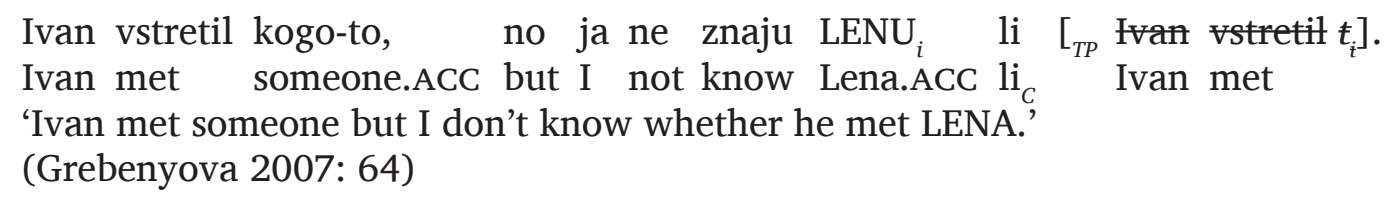

The interrogative conjunction $l i$ 'whether' can be a part of the double conjunction li...li, which can be translated as 'whether...or'. Since li...li consists of several occurrences of $l i$, each part of li...li has the syntactic properties of an individual li. In (15a), the Q-feature of $l i$ is valued by DP-movement: 
a. Ja ne znaju, myši li zašuršat na čerdake, krysy

1SG not know mice.NOM whether rustle.PRS.3PL on attic.LOC rats.NOM li zašuršat $\mathrm{V}$ podvale.

or rustle.PRS.3PL in basement.LOC

'I do not know whether mice rustle in the attic or rats rustle in the basement.'

b. *Ja ne znaju, li myši zašuršat na čerdake, li

1SG not know whether mice.NOM rustle.PRS.3PL on attic.LOC or

krysy zašuršat $\mathrm{v}$ podvale.

rats.NOM rustle.PRS.3PL in basement.LOC

'I do not know whether mice rustle in the attic or rats rustle in the basement.'

Note that the double interrogative conjunction li...li 'whether...or' cannot be used with phrases that are distinct from finite TPs. For instance, li...li 'whether...or' cannot coordinate VPs:

*Ona zastavila myšej li begat', sobak li lajat'.

3SG made mice.ACC whether run dogs.ACC or bark

'She made mice whether run, dogs or bark.'

In (16), li...li 'whether...or' fails to coordinate non-finite verbal complements of the causative verb make. Furthermore, li...li 'whether...or' cannot coordinate CP complements:
*Petja znaet, čto Saša li postroit dom, čto
Peter.NOM knows that Alex.NOM whether builds house.ACC that
Miša li kupit mašinu.
Mike.NOM or buys car.ACC
'Peter knows whether that Alex builds a house or that Mike buys a car.'

The ungrammaticality of (17) suggests that the lexical items li 'whether' and čto 'that' attempt to occupy the same structural position of the C-head, which results in an unresolvable conflict. The assumption that $l i$ 'whether' is a $\mathrm{C}$ with a question feature is corroborated by its syntactic compatibility. Clauses headed by $l i$ 'whether' cannot be complements to verbs that do not select questions:
a. Petja sprašivaet, Saša li postroit dom, Miša li Peter.NOM asks Alex.NOM either builds house.ACC Mike.NOM or kupit mašinu. buys car.ACC 'Peter asks whether Alex builds a house or Mike buys a car.'

b. *Petja znaet, Saša li postroit dom, Miša li Peter.NOM knows Alex.NOM either builds house.ACC Mike.NOM or kupit mašinu. buys car.ACC 'Peter knows whether Alex builds a house or Mike buys a car.'

In (17), li-clauses cannot be selected by the verb know, since this verb does not select questions. The verb ask, by contrast, selects questions, which makes it compatible with li-clauses. Interestingly, li...li 'whether...or' can only introduce clausal questions. For instance, li...li 'whether...or' is incompatible with DPs that have a question-like meaning: 
*Ona sprosila pro problem li, rešenie li. 3SG asked about problem.ACC whether solution.ACC or 'She asked whether about the problem or solution.'

In (19), li...li 'whether...or' fails to introduce the DP problem and the DP solution, even through the notion of question is encoded in their semantics. Thus, a question-like meaning does not suffice to make a phrase compatible with $l i . . . l i$ 'whether...or'.

Given the evidence discussed above, I conclude that li...li 'whether...or' is a compound question C, each part of which projects a CP. Since li-clauses are CPs, the most straightforward analysis of structures with li...li is to assume that clauses conjoined by li...li are coordinated CPs. The assumption that clauses headed by li...li are coordinated can be corroborated by their free permutation:

a. Ja ne znaju, myši li zašuršat na čerdake, krysy 1SG not know mice.NOM whether rustle.PRS.3PL on attic.LOC rats.NOM li zapiščat $\quad \mathrm{v}$ podvale. or squeak.PRS.3PL in basement.LOC

'I do not know whether mice rustle in the attic or rats squeak in the basement.'

b. Ja ne znaju, krysy li zapiščat $v$ podvale, 1SG not know rats.NOM whether squeak.PRS.3PL in basement.LOC myši li zašuršat na čerdake. mice.NOM or rustle.PRS.3PL on attic.LOC 'I do not know whether rats squeak in the basement or mice rustle in the attic.'

In (21), each of the coordinated CPs contains an independent T. Consequently, the sentences in (21) cannot be re-analysed as $v \mathrm{P}$ coordination, since the double conjunction li...li 'whether...or' cannot be merged at the $v \mathrm{P}$ level. Nevertheless, the double conjunction li...li 'whether...or' does provide a perfect environment for Gapping in Russian:
Ja ne znaju, myši
li zašuršat
na čerdake, krysy li
1SG not know mice.NOM whether rustle.PRS.3PL on attic.LOC rats.NOM or
zašurǔsat $\quad \mathrm{v}$ podvale.
rustle.PRS.3PL in basement.LOC
'I do not know whether mice rustle in the attic or rats rustle in the basement.'

Note that other pre-li elements are compatible with Gapping in li...li construction. For instance, pre-li elements compatible with Gapping can be adverbial PPs (see (22a)) and direct objects (see (22b)):

a. Ja ne znaju, V Evrope li rodilsja Vasja, v

1SG not know in Europe.LOC whether was.born Vasja.NOM in

Amerike li rodilsja Petja.

America.LOC or was.born Petja.NOM

'I do not know whether Vasja was born in Europe or Petja born in America.'

b. Ja ne znaju, vino li pil vivo li

1SG not know wine.ACC whether drink.PST.3SG Vasja.NOM beer.ACC or pil Petja.

drink.PST.3SG Petja.NOM

'I do not know whether Vasja drank wine or Petja drank beer.' 
Finally, binding properties of structures with li...li suggest that they cannot reduced to low coordination. The low coordination approach proposed by Johnson predicts that the subject in the first conjunct can c-command any elements in the second conjunct:

No actress ${ }_{i}$ can write a script or her ${ }_{i}$ agent ean write a screenplay.

(Potter et al. 2017:1144)

According to Johnson, the DP "no actress" in (23) originates in low coordination of $\nu \mathrm{P}$ and subsequently moves to [Spec, TP]:

$$
\left[_ { T P } \text { No actress } { } _ { i } [ \mathrm { T } ] \left[_{v P} \mathrm{t}_{i} \text { can write a script or her }{ }_{i}\right.\right. \text { agent ean write a screenplay]]. }
$$

The movement to [Spec, TP] allows the DP "no actress" to c-command the low coordination of $v \mathrm{Ps}$ and bind the pronominal determiner her. In contrast to low coordination, clauses introduced by li...li disallow c-commanding across the conjunct:

$$
\begin{aligned}
& \text { *Ja ne znaju, }\left[_{C P 1} \text { každaja }_{i} \mathbf{l i} \text { aktrisa }_{i}\right. \text { možet napisat' scenarij], } \\
& 1 \text { SG not know every whether actress.NOM can write script.ACC } \\
& {\left[_{C P 2} \text { ee }{ }_{i}\right. \text { li agent možet napisat' p'esu]. }} \\
& \text { her or agent.NOM can write play.ACC } \\
& \text { 'I do not know whether every actress can write a script or her agent ean write } \\
& \text { a play.' }
\end{aligned}
$$

In (25), li-clauses are coordinated CPs. Thus, the DP každaja aktrisa 'every actress' cannot c-command the DP ee agent 'her agent', since $\mathrm{CP}_{1}$, which dominates the DP každaja aktrisa 'every actress', does not dominate the DP ee agent 'her agent'. Consequently, c-commanding across the conjunct is illicit in ((25)). This suggests that clauses introduced by li...li do not involve low coordination. Otherwise, the binding in (25) would be grammatical.

To sum up, Gapping must not be restricted by low coordination. Otherwise it would be impossible to account for the compatibility of the double conjunction li...li 'whether...or' with Gapping.

\section{Modal scope as the redemption of low coordination}

In the previous section, I have provided evidence that Gapping cannot be exclusively based on low coordination. Thus, one could conclude that low coordination should not play any role in Gapping derivation. However, there are cases that can be elegantly explained if one adopts low coordination as a component of Gapping. The necessity of low coordination is corroborated by modal scope phenomena.

In (26), the negated modal can't must have a wide scope interpretation under the specified context, since James can order caviar when he does not have dinner with Jane. Consequently, it is not the case that James orders caviar and Mary orders sushi at the same time:

(26) a. James can't order caviar and Mary chili.

b. Context: James and Mary are having dinner together at a restaurant that serves just caviar and chili. James is an extremely wealthy caviar lover and Mary is an extremely poor chili lover. James' sensitive conscience won't permit him to order an expensive dish when Mary orders an inexpensive one. However, James generally has no problem with expensive menu choices and is inclined to prefer them. 
c. Wide scope $\neg \diamond(\mathrm{P} \wedge \mathrm{Q})$ : True

d. Distributive scope $\neg \diamond \mathrm{P} \wedge \neg \diamond \mathrm{Q}$ : False (Potter et al. 2017: 1127)

Low coordination allows us to account for the wide modal scope by placing the modal verb above the coordination of $v$ Ps. Although (26) suggests that Gapping is low coordination, there are constructions that disallow wide scope interpretation:

a. James can't order caviar or Mary chili.

b. Context: James and Mary are having dinner together at a restaurant that serves just caviar and chili. James is an extremely wealthy caviar lover and Mary is an extremely poor chili lover. James' sensitive conscience won't permit him to order an expensive dish when Mary orders an inexpensive one. However, James generally has no problem with expensive menu choices and is inclined to prefer them.

c. Wide scope $\neg \diamond(\mathrm{P} \vee \mathrm{Q})$ : False

d. Distributive scope $\neg \diamond \mathrm{P} \vee \neg \diamond \mathrm{Q}$ : True

(Potter et al. 2017: 1128)

In (26), wide scope is unavailable, since it is possible for Mary to order chili, which render the negation of disjunction false. If one assumes that Gapping is pure low coordination, narrow scope is unexpected.

Furthermore, the following Russian cases demonstrate that both scope readings are available for one Gapping sentence:

$$
\begin{aligned}
& \text { Petja ne možet est' ikru, a Saša čili. } \\
& \text { Petja not can eat caviar and Saša chilli } \\
& \text { 'Petja cannot eat caviar and Saša chilli.' }
\end{aligned}
$$

a. $\neg \diamond(\mathrm{P} \& \mathrm{~V})$

\section{Context:}

Petja and Saša are having dinner together at a restaurant that serves just caviar and chili. Petja is an extremely wealthy caviar lover and Saša is an extremely poor chili lover. Petja's sensitive conscience won't permit him to order an expensive dish when Saša orders an inexpensive one. Saša is willing to order chilli. Thus, caviar and chilli cannot be ordered simultaneously and Petja will also order chilli.

\section{Meaning:}

It is not possible for Petja to eat caviar and for Saša to eat chilli.

b. $(\neg \diamond \mathrm{P} \& \neg \diamond \mathrm{V})$

\section{Context:}

Petja and Saša are having dinner together at a restaurant that serves caviar and chilli. However, other dishes are also served at this restaurant. Petja and Saša are wealthy food connoisseurs and can order anything they like. However, Petja does not like caviar and Saša does not like chilli.

\section{Meaning:}

Petja and Saša have different food preferences. Petja cannot eat caviar and Saša cannot eat chilli. 
In (28), the negated modal ne možet 'cannot' can have wide scope interpretation if it is not possible for Petja to eat caviar and for Vanja to eat beans. Moreover, narrow scope interpretation of (28) is also available, since (28) can be a statement about two independent food preferences. Although (28) has ambiguous scope interpretation, there are Gapping cases that are compatible with only one type of modal scope. Consider, for instance, the li...li construction:

$$
\begin{aligned}
& \text { Ja ne znaju, pivo li ne možet zakazat' Vasja, vino } \\
& \text { 1SG not know beer.ACC whether not can order Vasja.NOM wine.ACC } \\
& \text { li ne možet zakazat' Petja. } \\
& \text { or not can order Petja.NOM } \\
& \text { 'I do not know whether Vasja cannot order beer or Petja eannot order wine.' }
\end{aligned}
$$

\section{Context:}

Petja and Vasja go to a pub. Petja is a wine connoisseur. Thus, Petja is snobbish and strongly disapproves of beer lovers. At a pub, Petja always orders wine. By contrast, Vasja is a tactful person and tries not to annoy Petja. So Vasja will not order beer.
a. Wide scope $\neg \diamond(\mathrm{P} \vee \mathrm{V})$ : False
It cannot be the case Peter orders wine or Vasja orders beer.
b. Distributive scope $\neg \diamond(\mathrm{P}) \vee \neg \diamond(\mathrm{V})$ : True
Peter cannot order wine or Vasja cannot order beer.

In (29), the li...li construction is compatible only with distributive scope. Since Petja always orders wine, the disjunction $P \vee V$ will be true. Thus, negation of $P \vee V$ is false and wide scope is unavailable. Distributive scope is the only available interpretation of ((29)). The reason is that Vasja cannot allow himself to order beer. Consequently, the disjunction $\neg \diamond(\mathrm{P}) \vee \neg \diamond(\mathrm{V})$ is true. When it comes to scope, li...li 'whether...or' is similar to the English conjunction or in (26).

To account for modal scope interpretations, I propose that Gapping stems from two sources, which are low coordination of $v$ Ps and high coordination of TPs/CPs. I also argue that Gapping is derived by Parallel Merge, which allows a node to be dominated by several mothers (see Citko 2005). Parallel Merge is schematically represented by the following tree:

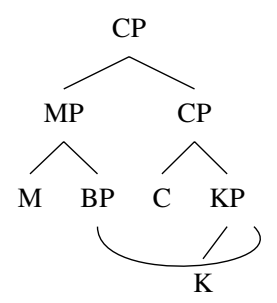

In (29), MP (the goal phrase of BP) does not dominate KP (the source phrase of BP), which makes Parallel Merge different from Internal Merge. In the present squib, I will not discuss the exact algorithm used to linearize structures like (29). To put it simply, only BP dominated by MP will be pronounced at PF. If we apply this rule to Gapping, nodes shared between clauses are pronounced only in the first clause.

As is mentioned in the introduction, low coordination provides us with a straightforward analysis of wide scope. Low coordination derives wide scope by placing the modal operator above coordination: 


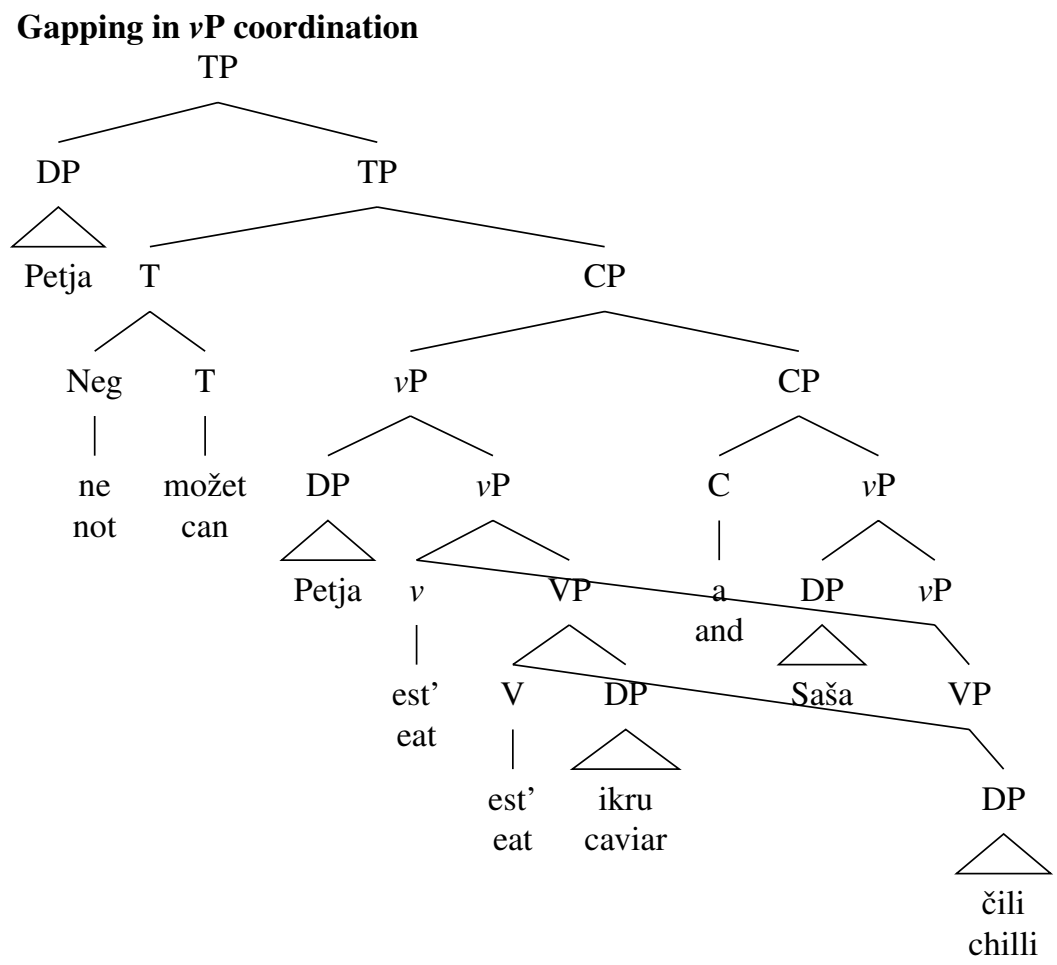

High coordination derives distributive scope, as there are two independent TPs and each of these TPs has a modal verb and a negation head. The fact that the negated modal operator is shared does not affect the distributive interpretation. The negated modal operator is still present in each TP: a T-head is required to project a TP. Thus, the modal verb and the negation head are distributed between TP-conjuncts, which gives rise to distributive interpretation:

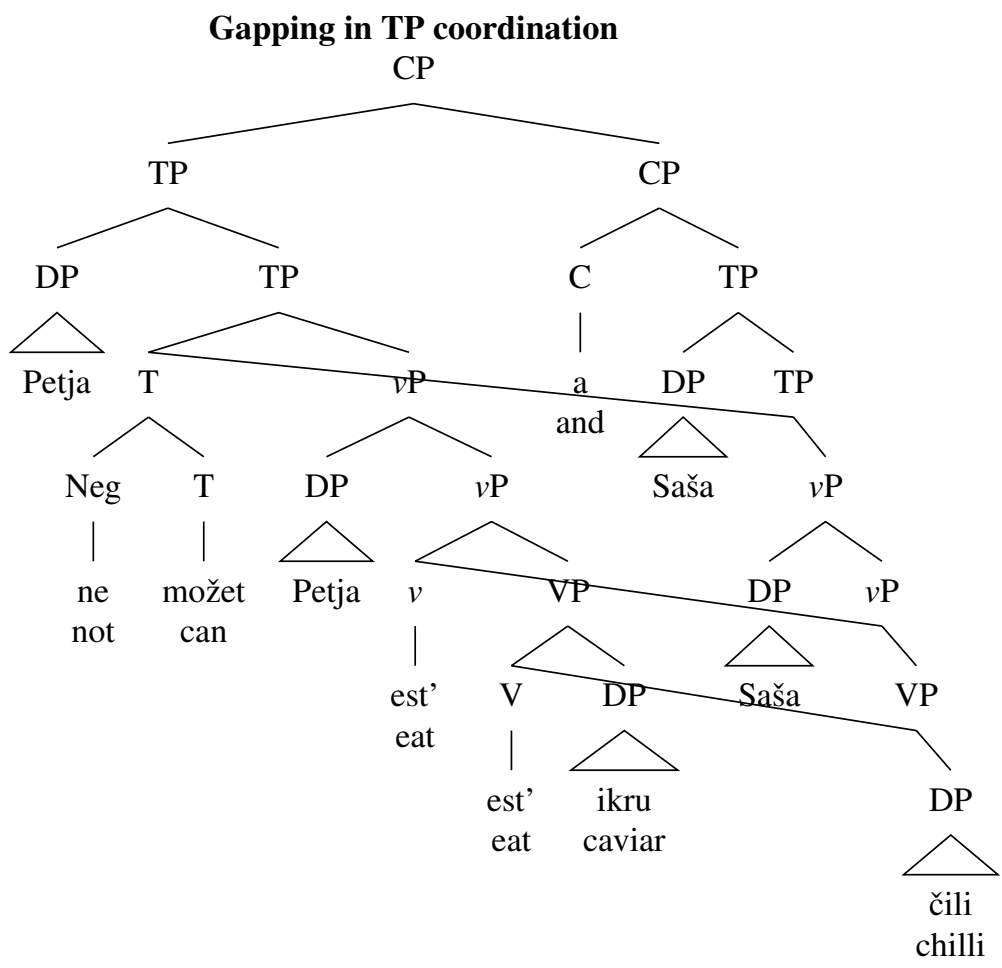

Note that the analysis proposed above can be extended to CP coordination. Recall the Gapping clause with li...li 'whether...or': 

Ja ne znaju, myši
li zašuršat
na čerdake, krysy
li
1sG not know mice.NOM whether rustle.PRS.3PL on attic.LOC rats.NOM or zašuršat $\quad \mathrm{V}$ podvale.
rustle.PRS.3PL in basement.LOC
'I do not know whether mice rustle in the attic or rats rustle in the basement.'

If one analyses (33) as high coordination with applications of Parallel Merge, the CP coordination in (33) will derive the following tree structure:

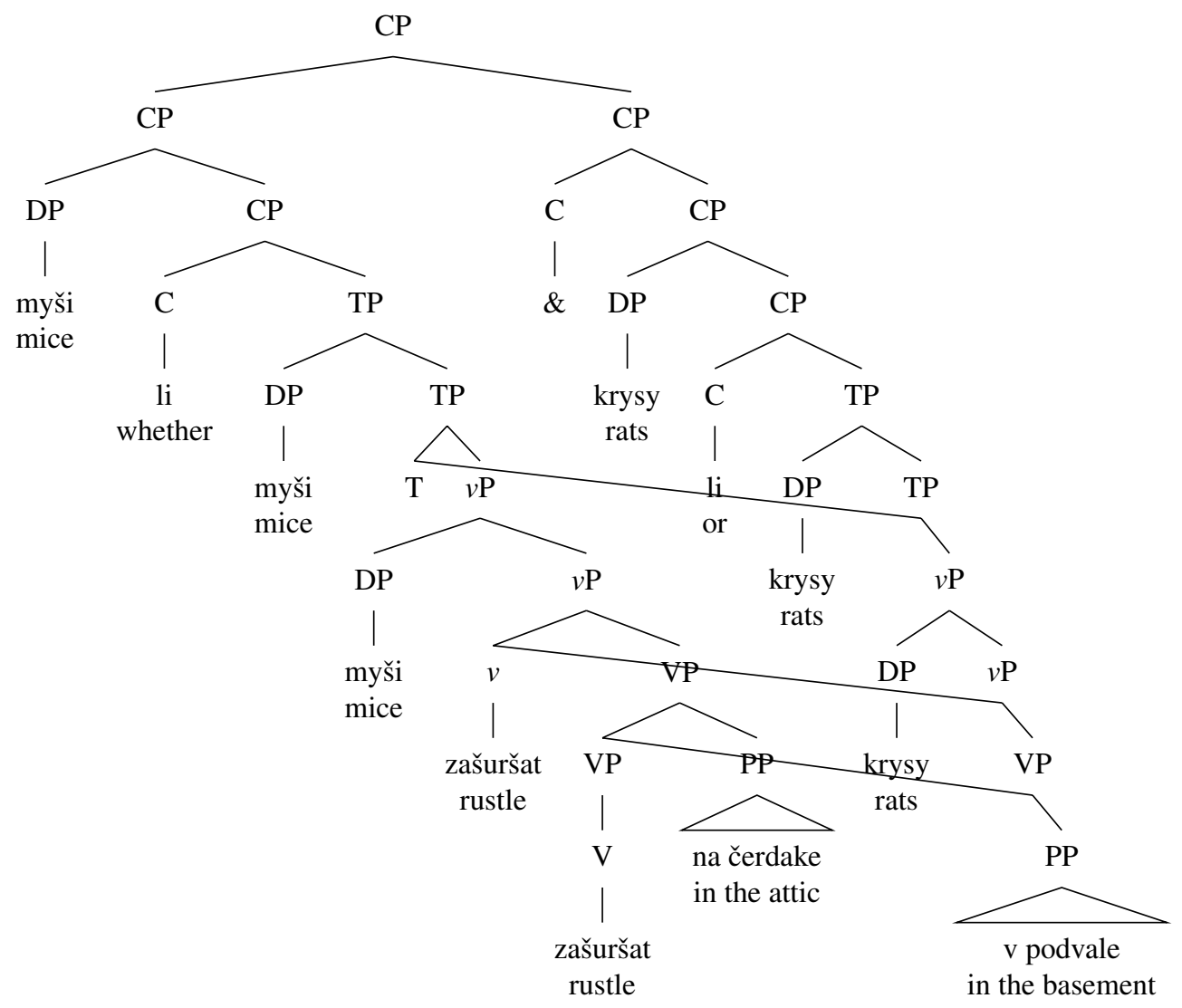

To conclude this squib, I explain the necessity of low coordination from a minimalist viewpoint. Low coordination is a preferred option as it requires fewer applications of Parallel Merge, as all heads and phrases located above $v \mathrm{P}$ coordination do not need to be shared (see (30)). Under high coordination, there are two independent TPs, which leads to more applications of Parallel Merge (see (31)). Crucially, Parallel Merge allows us to avoid ATB movement proposed by Johnson.

\section{Abbreviations}

$\mathrm{NOM}=$ nominative, $\mathrm{ACC}=$ accusative, $\mathrm{INS}=$ instrumental, $\mathrm{LOC}=$ locative, $\mathrm{PRS}=$ present, $\mathrm{PST}=$ past, $\mathrm{PL}=$ plural, $\mathrm{SG}=$ singular, $1=$ first person, $3=$ third person.

\section{Acknowledgements}

I wish to thank my supervisor David Adger for his continuous and rigorous support during my research time spent at QMUL.

\section{Competing Interests}

The author has no competing interests to declare. 


\section{References}

Agafonova, Irina. 2014. On syntax-semantics of gapping constructions. In Proceedings from the annual meeting of the chicago linguistic society 46. 1-16.

Bailyn, John Frederick. 2012. The Syntax of Russian. Cambridge University Press.

Citko, Barbara. 2005. On the Nature of Merge: External Merge, Internal Merge, and Parallel Merge. Linguistic Inquiry 36. 475-497. DOI: https://doi.org/10.1162/002438 905774464331

Citko, Barbara. 2011. Symmetry in Syntax: Merge, Move and Labels. Cambridge: Cambridge University Press.

Grebenyova, Lydia. 2007. Sluicing in Slavic. Journal of Slavic Linguistics 15(1). 49-80.

Johnson, Kyle. 2009. Gapping is not (VP-)ellipsis. Linguistic Inquiry 40. 289-328. DOI: https://doi.org/10.1162/ling.2009.40.2.289

Lin, Vivian I-Wen. 2002. Coordination and sharing at the interfaces: Massachusetts Institute of Technology dissertation.

Merchant, Jason. 2001. The syntax of silence: Sluicing, islands, and the theory of ellipsis. Oxford: Oxford University Press.

Merchant, Jason. 2013. Voice and Ellipsis. Linguistic Inquiry 44. 77-108. DOI: https://doi. org/10.1162/LING_a_00120

Potter, David Keith, Michael Frazier \& Masaya Yoshida. 2017. A two-source hypothesis for Gapping. Natural Language and Linguistic Theory 35(4). 1123-1160. DOI: https:// doi.org/10.1007/s11049-017-9359-y

Toosarvandani, Maziar. 2013. Gapping is low coordination (plus VP-ellipsis): A reply to Johnson. MIT.

How to cite this article: Kalinin, Aleksandr. 2020. Gapping is not only low coordination. Glossa: a journal of general linguistics 5(1): 46.1-13. DOI: https://doi.org/10.5334/gjgl.1044

Submitted: 24 July 2019 Accepted: 01 March 2020 Published: 12 May 2020

Copyright: $\odot 2020$ The Author(s). This is an open-access article distributed under the terms of the Creative Commons Attribution 4.0 International License (CC-BY 4.0), which permits unrestricted use, distribution, and reproduction in any medium, provided the original author and source are credited. See http://creativecommons.org/licenses/by/4.0/.

$\mathrm{u}[\quad$ Glossa: a journal of general linguistics is a peer-reviewed open access journal published by Ubiquity Press. 